\title{
Calcium and fat absorption by low birthweight infants from a calcium-supplemented milk formula
}

\author{
D. BARLTROP and T. E. OPPÉ \\ From the Paediatric Unit, St. Mary's Hospital Medical School, London
}

\begin{abstract}
Barltrop, D., and Oppé, T. E. (1973). Archives of Disease in Childhood, 48, 580. Calcium and fat absorption by low birthweight infants from a calciumsupplemented milk formula. The retention of calcium and fat by low birthweight infants from two milks differing only in their calcium content has been determined. Calcium supplementation of the milk formula resulted in enhanced retentions of calcium, but the retention of fat was unaltered. The findings suggest that insufficient absorption of calcium may be a factor in neonatal tetany.
\end{abstract}

The metabolism of calcium by the newborn infant is incompletely understood, and the precise mechanisms for the control of neonatal calcium homoeostasis have yet to be defined. In some infants who are fed preparations of cow's milk the plasma calcium concentration may decrease sufficiently to result in hypocalcaemic tetany, but there is no general agreement concerning the mechanism of this or its prevention. Among the dietary factors, the high phosphate load of cow's milk feeds (Oppé and Redstone, 1968), intraluminal soap formation (Widdowson, 1969), and inappropriate dietary $\mathrm{Ca} / \mathrm{P}$ ratio (Barltrop and Oppé, 1970) have all been implicated. A further factor which has attracted less attention is the low positive or negative retention of calcium that may occur in some infants during the early neonatal period (Widdowson, 1965). It is likely that factors giving rise to increased faecal losses of calcium compared with absorption may exacerbate the tendency to hypocalcaemia in the neonate.

Calcium supplementation of cow's milk formulae will prevent a significant decrease in the neonatal plasma calcium concentration (Barltrop and Oppé, 1970), but it is not known whether this is achieved by enhanced calcium absorption or by some other mechanism. Some increased calcium soap formation might be expected to result from calcium supplementation of the milk and, though unlikely to be of clinical significance, some decrease in the absorption of dietary fat might also be anticipated (Holt et al., 1935).

Previous work on this problem has been concerned with term infants of normal birthweight, but less is

Received 20 November 1972. known concerning the absorption of minerals from the gut of low birthweight infants. In this paper the absorption of calcium and fat by low birthweight infants from two experimental milk formulae differing only in their calcium content is reported.

\section{Methods}

Infants nursed in the special care baby unit during a period of 28 months from October 1969 were studied. They were selected consecutively as they became available within 5 to 41 days after birth, provided they were not breast fed, had no gastrointestinal disturbance or other symptom, and parental consent to the investigation had been given. Each infant was given only the test formula from birth to the metabolic balance. Gestational age was estimated in each case by the paediatric staff, taking into account clinical evaluation (Dubowitz, Dubowitz, and Goldberg, 1970) and the obstetric data.

The balance technique was that described by Widdowson (1965) in which feeds prepared to constant dilution were offered during a 3-day period with carmine markers added to the first and last feeds. The amount taken at each feed was determined by weight to the nearest $0.1 \mathrm{~g}$. Throughout the balance period, stools and regurgitated material were collected on specially prepared, acid-washed nylon napkins and bibs covered with polyethylene sheet. No provision was made for the separate collection of urine. All specimens were stored at $4{ }^{\circ} \mathrm{C}$ before preparation according to a strict protocol. After manual separation of faecal or regurgitated material, the bibs and napkins were brushed, and subsequently boiled in warm $1 \% \mathrm{HCl}$, boiled in deionized water, and rinsed twice in cold deionized water. The washings and faeces were combined and homogenized with a Silverson mixeremulsifier and the volume measured. Aliquots of the prepared milk and faecal homogenate were obtained and 
the total fat and calcium content of each was determined using the method of van de Kamer, Huinink, and Weyers (1949) and atomic absorption spectrophotometry, respectively. The mean weight of each infant was determined for each balance period and the net retention (intake minus faecal excretion) of calcium and fat per unit body weight was calculated.

The two milks studied were prepared by Glaxo Laboratories from a carbohydrate modified cow's milk formula adjusted to constant fat/protein ratio and incorporating appropriate supplements of vitamins and iron. One of the milks (Formula A) was used unmodified, and the second (Formula B) contained supplementary calcium which had been added during manufacture as calcium lactate. The formulation of the two milks is given in Table I.

\section{TABLE I}

Composition of milk formulae per $100 \mathrm{ml}$

\begin{tabular}{l|c|c}
\hline & Formula A & Formula B \\
\hline Fat (g) & $2 \cdot 8$ & $2 \cdot 8$ \\
Carbohydrate (g)t & $9 \cdot 9$ & $9 \cdot 9$ \\
Protein (g) & $1 \cdot 8$ & $1 \cdot 8$ \\
Calcium (mg) & $62 \cdot 4$ & $93 \cdot 9$ \\
Phosphorus (mg) & $52 \cdot 8$ & $52 \cdot 8$ \\
Ca/P & $1 \cdot 2$ & $1 \cdot 8$ \\
\hline
\end{tabular}

\section{*Butterfat.}

†Lactose $52 \%$ + maltodextrins $48 \%$.

\section{Findings}

Twenty-four infants of mean postnatal age $14 \cdot 4$ ( 5 to 41 ) days and mean gestational age $35 \cdot 7$ (27 to 42) weeks were studied. The infants comprised 2 groups which were fed Formula A and Formula B, respectively. The basic balance data for the two groups are given in Table II, together with details of weight, age, and maturity. There were no significant differences in their gestational ages at birth, in clinical progress, or in the nature and frequency of the stools.

The mean retention of fat by infants fed Formula
A was $1.91 \mathrm{~g} / \mathrm{kg}$ per day (SD 0.81 ) compared with $2 \cdot 22 \mathrm{~g} / \mathrm{kg}$ per day (SD 0.37 ) by infants fed with the calcium-supplemented formula. The difference in retention of fat by the two groups was not significant.

The absorption of calcium by the two groups differed markedly. Many of the infants fed Formula $\mathrm{A}$ were in low positive or negative balance, so that the mean calcium retention by this group was $-3 \cdot 1 \mathrm{mg} / \mathrm{kg}$ per day. The infants fed with the calcium-supplemented milk (Formula B), however, were all in positive calcium balance and had a mean retention of $+62 \cdot 5 \mathrm{mg} / \mathrm{kg}$ per day (SD 27.3) (Fig.). Comparison of the means using the ' $t$ ' test showed that they differed significantly $(P=0.001)$.

The retention of calcium in both cases was small compared with the intake of calcium in the milk and the retention of fat was also incomplete.

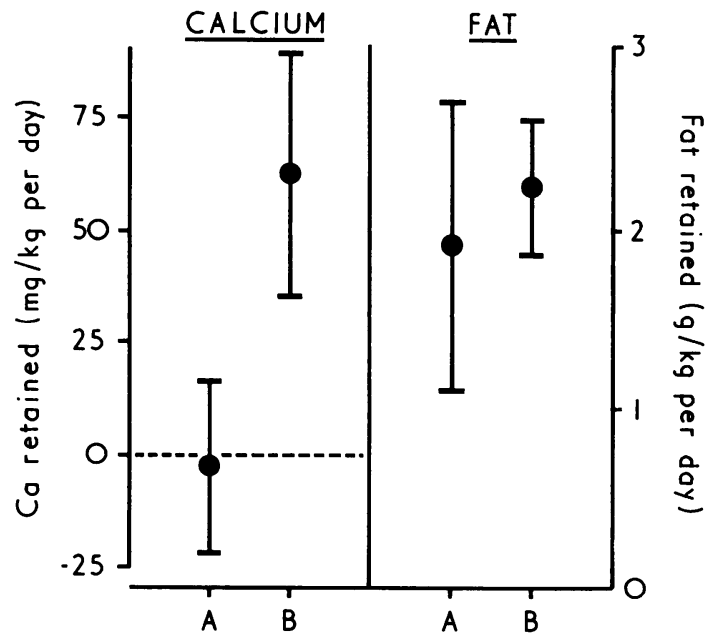

FIG.-Fat and calcium retentions by low birthweight infants fed Formula $A($ no. $=20)$ compared with $a$ calcium-supplemented milk, Formula $B($ no. $=4)$. Mean values $\pm S D$.

TABLE II

Mean data from 3-day balance periods for infants fed basic and calcium-supplemented formulae*

\begin{tabular}{|c|c|c|c|c|c|c|}
\hline No. & $\begin{array}{l}\text { Age } \\
\text { (dy) }\end{array}$ & $\begin{array}{c}\text { Age }+ \text { gestational } \\
\text { age }(\mathrm{dy})\end{array}$ & $\begin{array}{l}\text { Weight } \\
\text { (kg) }\end{array}$ & $\begin{array}{l}\text { Milk } \\
\text { intake } \\
\text { (ml) }\end{array}$ & $\begin{array}{l}\text { Fat } \\
\text { excreted } \\
\quad(g)\end{array}$ & $\begin{array}{c}\text { Calcium } \\
\text { excreted } \\
(\mathrm{mg})\end{array}$ \\
\hline $\begin{array}{l}\text { Formula A } \\
\quad 20\end{array}$ & $\begin{array}{l}13 \cdot 4 \\
(7 \cdot 8)\end{array}$ & $\begin{array}{l}25 \cdot 3 \\
(3 \cdot 3)\end{array}$ & $\begin{array}{c}1 \cdot 74 \\
(0 \cdot 42)\end{array}$ & $\begin{array}{l}1003 \\
(275)\end{array}$ & $\begin{array}{l}15 \cdot 8 \\
(5 \cdot 7)\end{array}$ & $\begin{array}{c}667 \\
(216)\end{array}$ \\
\hline $\begin{array}{l}\text { Formula B } \\
\quad 4\end{array}$ & $\begin{array}{c}19 \cdot 8 \\
(14 \cdot 8)\end{array}$ & $\begin{array}{l}37 \cdot 9 \\
(3 \cdot 7)\end{array}$ & $\begin{array}{c}2 \cdot 13 \\
(0 \cdot 12)\end{array}$ & $\begin{array}{l}1276 \\
(163)\end{array}$ & $\begin{array}{l}19 \cdot 6 \\
(2 \cdot 1)\end{array}$ & $\begin{array}{c}974 \\
(204)\end{array}$ \\
\hline
\end{tabular}

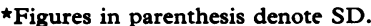




\section{Discussion}

The increased retention of calcium by infants fed with a calcium-supplemented formula suggests that dietary factors play an important role as determinants of absorption in addition to the intestinal mucosa. These studies do not allow the limiting factors to be identified, though soap formation with unabsorbed fatty acids cannot be excluded. Provided that a concentration gradient effect can be excluded, it seems that the provision of additional calcium in the diet allows increased absorption to occur both absolutely and as a percentage of the intake. The addition of calcium to a milk formula will result in an increased $\mathrm{Ca} / \mathrm{P}$ ratio which has already been shown to modify the resultant plasma calcium concentrations irrespective of the total mineral load in the infant's diet (Barltrop and Oppé, 1970). The mineral content of both milks in this study was greater than breast milk, though the $\mathrm{Ca} / \mathrm{P}$ ratio was less. The findings were consistent with studies in adults in which it has been shown that increased dietary calcium intake results in increased urinary excretion (Knapp, 1947), presumably secondary to increased intestinal absorption.

Conventional balance techniques measure only net retention (intake minus faecal excretion) of calcium and do not provide a true index of absorption. This must be taken into account in the interpretation of low positive and negative calcium balances that were found in infants fed Formula A, since no assessment of the faecal endogenous calcium excretion could be made. Studies with stable enriched isotopes of calcium have suggested that the endogenous contribution of calcium to the faeces in the premature infant may be of a similar order of magnitude to the calcium removed from the diet by absorption (Barltrop and Sutton, 1972). A low positive or negative calcium balance in infancy does not, therefore, necessarily imply a decreased absorption of calcium from the gut.

The findings cannot be extrapolated to older or more mature infants since it is known that the efficiency of absorption in the neonate may increase with age (Barltrop and Oppé, 1973). Similarly, the physiological significance is uncertain since the total body calcium is relatively large at birth and the period of poor net retention of calcium from milks of low $\mathrm{Ca} / \mathrm{P}$ ratio is of limited duration. It is possible, however, that the homoeostatic mechanisms for the maintenance of the plasma calcium concentration in the newborn may be inadequate in the presence of a low positive or negative calcium balance. Neonatal hypocalcaemia might thus reflect an inability to mobilize skeletal calcium or to limit losses from the calcium pool to bone, urine, or the intestinal lumen sufficiently to prevent a decrease in the plasma calcium concentration.

The milk formulae were devised in collaboration with Dr. W. F. J. Cuthbertson (Glaxo Research Ltd.) and were prepared by Glaxo Laboratories Ltd. Miss C. Copland and Mrs. P. Dillon undertook the metabolic balances. Mrs. C. Harford and Mrs. H. Rotholz made the chemical analyses. D. B. is a Wellcome Senior Fellow in Clinical Science. Part of the costs were defrayed by a grant from the Children's Research Fund.

\section{REFERENCES}

Barltrop, D., and Oppé, T. E. (1970). Dietary factors in neonatal calcium homoeostasis. Lancet, 2, 1333.

Barltrop, D., and Oppé, T. E. (1973). Absorption of fat and calcium of low birthweight infants from milks containing butterfat and olive oil. Archives of Disease in Childhood, 48, 496.

Barltrop, D., and Sutton, A. (1972). The use of ${ }^{46} \mathrm{Ca}$ to measure $\mathrm{Ca}$ absorption in the neonate. In Nuclear Activation Techniques in the Life Sciences. I.A.E.A.-SM-157/45, Vienna.

Dubowitz, L. M. S., Dubowitz, V., and Goldberg, C. (1970). Clinical assessment of gestational age in the newborn infant. Fournal of Pediatrics, 77, 1.

Holt, L. E., Tidwell, H. C., Kirk, C. M., Cross, D. M., and Neale, S. (1935). Studies in fat metabolism. I. Fat absorption in normal infants. Fournal of Pediatrics, 6, 427.

van de Kamer, J. H., Huinink, H.ten B., and Weyers, H. A. (1949) Rapid method for the determination of fat in feces. Fournal of Biological Chemistry, 177, 347.

Knapp, E. L. (1947). Factors influencing the urinary excretion of calcium. I. In normal persons. Fournal of Clinical Investigation, 26, 182.

Oppé, T. E., and Redstone, D. (1968). Calcium and phosphorus levels in healthy newborn infants given various types of milk. Lancet, 1, 1045.

Widdowson, E. M. (1965). Absorption and excretion of fat, nitrogen, and minerals from 'filled' milks by babies one week old. Lancet, 2, 1099.

Widdowson, E. M. (1969). Preparations used for the artificial feeding of infants. Fournal of the Royal College of Physicians, 3, 285.

Correspondence to Dr. D. Barltrop, Paediatric Unit, St. Mary's Hospital Medical School, London W.2. 